\title{
Analyses Turkish-Israeli Cooperation in the Context of Turkey's “Zero Problem” Foreign Policy
}

\begin{abstract}
Ali Se rdar Erdurmaz
Hasan Kaly oncu University, Hava Limanı 8. Km. Sahinbey/Gaziantep-Turkey and General Coordinator in Turksam International Relations and Strategic Analy sis Centre, Barış Manco Mah. 1388 Sok. No. 52 Balgat/Ankara, Turkey

Abstract After the cold war era in 1990's, Turkey was in a position of seeking a partner in the Middle East that could provide cooperation in grooving security challenges from its Middle Eastern neighbours. Because of its geo-strategic importance in the regionshe has done the threat assessments again and has taken the necessary decisions to modernize her armed forces since the second half of 1990's. However, refrained contributions with the pretext of human rights violations of U.S.A. and western countries has led Turkey to put Israeli military and defence industry cooperation in the agenda. Turkish-Israeli relations that continued in a particular order since 1994 abruptly reached a braking point with a series of events after Israeli attack in Gazza at the end of 2008. What has changed in the situation to deteriorate the bilateral relations? This article analyses the changing trends in military and security relations between Turkey and Israel in regard to Justice and Development Party government new foreign policy "zero problem with neighbours". It identifies factors that influence the deterioration of relations between two countries and puts forward the overall picture of the current situation.
\end{abstract}

Keywords Turkey, Israel, Defence industry, Turkey-Israel relations, Modernization

\section{Introduction}

Speaking on the relations with Israel, Turkish Prime Minister Recep T. Erdogan expressed his feelings saying that "Today is a turning point in history. Nothing will be the same again", immediate after raid on flotilla by Israel soldiers (1).

Actually bilateral relations, began in January 1994 with the visit of Israeli President Ezer Weizman, have been deteriorating since Israel's military campaign to Gazza Strip against Hamas between the end of 2008 and the early of 2009 (1). Prime Minister Erdogan consider himself insulted that then Israeli Prime Minister Ehud Olmert had refrained from informing him of the anticipated offensive while he was in Turkey (2)Th is failure would be the breaking point of the relations in military and defence industry which came in a particular order since 1994.

Thus following Israeli President Weizman visit without losing any time, in 1996 a lone three agreements were signed between two states covering three main subjects which were important for both countries.

First issue was the cooperation in the defence industry. At the early of 1990's Turkey decided to update of its armed forces. After the collapse of the Soviet Union, a strategic gap emerged in the Middle East, the Balkans and the Caucasus,

* Corresponding author:

serdarerdurmaz@gmail.com (Ali Serdar Erdurmaz)

Published online at http://journal.sapub.org/jgt

Copyright (C) 2012 Scientific \& Academic Publishing. All Rights Reserved brought before the new threat assessments on the agenda. Therefore, each state has adapted both modernization and reconstruction programs to build up the sufficient conventional power in order to deter and provide the superiority over the other states.

When the topic discussed in terms of Turkey, especially with the end of the Cold War era, Turkey determines forming the basis for its own defence industry infrastructure to develop a new strategy to implement a modernization program. In order to establish its national defence industry, Turkey must provide two important entries fro $m$ the western suppliers; the first; to impose suppliers "to make a joint production" to educate her engineers to build up its own production infrastructure and the latter; to collaborate with the vendors to make a "technology transfer" in order to provide in its internal defence industry by establishing production facilities within Turkey.

Therefore, aftermath of the Cold War era, Turkey sought the countries to cooperate with her on both two issues. In Turkey's quest to help, U.S. and European countries have shown an attitude rather than a barrier. Democracy, human rights and rule of law issues came as prerequisite or preventive factors by the West in sales. Turkey, in the face of these negative outputs of the West has been in search of available resources especially to provide weapons and equipment to use against terrorism. Necessarily, she has turned her face to Russia and China. But in terms of NATO standards, it should not also be possible for Turkey as a NATO member to enter into collaboration on conventional weapons with the Russian Federation and China. 
In this case for Turkey, Israel has emerged as the most appropriate resource in the Middle East who is struggling to exist and, therefore, having high-tech defence industry. Israel assessed that cooperation with Turkey which has geographic, historic and geo-politic depth in the Middle East would be her own interest and gave the green light to make technology transfer and joint production in the modernization of the Turkish armed forces. Subject relations carried out without any problem up until the crisis emerged in Davos. These relations with Israel played an important role in establishing the in frastructure of the Turkish defence industry.

The second issue was military-to-military cooperation. In mid-1990 after collapse of the Cold War era within the turmo il Turkey multi- faced threat perception either from PKK terro ris $m$ or Syria, Iraq and Greece. Besides Iran also was a main problem for Israel and Turkey. Both countries would gain strength having military cooperation against the concerned threats by giving the posture that both of them were allies. Addition to that Israel had many advantages in time of war with new tie (3). The fact that Turkey was able to ensure strategic depth in the region which she needs to encounter a potential threat made this cooperation attractive for Israel.

And latest was the intelligence exchange which can be considered in military-to military relations but we separate it to put an emphasis on this issue. Two countries also shared intelligence. Israel was able to gather intelligence from Turkey on potential threats that are hard for Israel to reach and gather intelligence such as Iraq, Iran, and Syria etc. In return for, Turkey has gained the military know-how from Is rael, in dealing with the PKK (4).

However, mistrust of Justice and Development Party (AKP) put forward "one minute" event with the incident have been released in early 2009, and in 2010 Mavi Marmara case was the point of interruption of both countries relations. Turkey declared to implement sanctions on Israel in case of rejection of her claims, and has suspended bilateral military agreements and relationships severed.

This article, deals with the issues of cooperation and relation on above mentioned subjects, i.e.; defence industry, military and intelligent relations between two countries. Dwelling on the is sue of cooperation between Turkey-Israel defence industries, the military and intelligence tried to put forward to point reached and the situation reached upon discontinuation of these relations will be discussed in the light of empirical and theoretical methods. And at this point it will be provided some conclusions as the current and future states of Turkey and Israel mutual relations. Contribution of Jewish lobby in USA to strengthening Turkish position in US Parliament and other political issues is not discussed because it is out of scope of this report. However as a conclusion a view will be put forward that who is winner or loser after their tough position against each other's demand.

\section{Initiation of Turkish Israeli partnership}

In November 1947, in UN meeting Turkey took place against the decision and initially refused to recognize Israel. Later, in March 28, 1949 Turkey was the first Muslim country to recognize Israel and started at the level of representation in diplomatic relations. Because of Israel's struggle against communis $\mathrm{m}$ in the $1950 \mathrm{~s}$, Turkey has given special attention to relations with Israel. This situation resulted from the desire to improve the cold relations with America by means of Jews lobby in this country. In 1967 and 1973 wars this relation continued with ups and downs. The main reason is that Turkey also wanted to maintain a balanced relationship both with Israel and Arab countries. Economically, Turkey especially needs the Arabs, due to the oil requirement. Upon the annexation of East Jerusalem to Israel in the early 1980's Turkey downgraded diplomat ic relation to the lowest point in response to this action (5).

The revival of relations initiated again by appointment of a senior diplo mat as Chargé $d$ 'affa irs from Turkey to Israel in 1986 and increased in line with the Embassy after the Madrid Conference in October 1991.

Ahmet Davutoglu, Turkish Minister of Foreign Affairs, stated in his book titled "strategic depth"; "Israel's one of the main security concerns is to ensure active support or at least passive impartiality of the non-Arab countries in the Middle East. Immediately after the establishment of Israel, she has developed the concept of "periphery pact" that envisaged to enter into close co-operation with non-Arab countries such as Turkey and Iran which surround Arab countries (6). In fact, relations of both countries really began on the date of August 29 1958. Israeli Prime Minister David Ben-Gurion and Turkish Prime Minister Adnan Menderes meet secretly to agree upon the "peripheral pact". This pact was established against pan-Arabism and communis $\mathrm{m}$ (7). This meeting would be the cause to re-alive the relations between two countries frozen by Turkey after Israel's attack to Egypt in 1956. Thus, the low profile diplomatic and civilian cooperation between both countries also covered the military aspects in an increasing manner. And it was lasted up within a particular secrecy and cover until the end of 2009 (7). Towards the end of the1990's, while conservative groups were in power or in opposition exp ressed hard warnings and took up the stiff opposition to size of these relationships, the stable attitude of the Turkish Armed Forces has helped to come up unscathed of these relations until 2009.

The first agreement between Turkey and Israel in the military field was "Military Training and Cooperation Agreement" conducted by Deputy Chief of Staff, General Cevik Bir, in 23 February 1996. However in the military field there were two agreements made respectively; in 1994 "Security and Confidentiality Agreement" and in 1995 "The Memorandum for the Pilots Education" (8). Although as the third agreement this has been a very important step (9). The military agreements on December 1996 have produced unprecedented military cooperation in the realization of the two countries jo int air and naval exerc is es. According to this, both countries have opened mutually the use of airs pace and 
thus the possibility of Konya air facilities would be available to use of Israel's air fighters exercise. "Defence Industry Cooperation Agreement" was followed in August 26, 1996. And, with this agreement, as well as jo int military training, Israel would provide the modernization of Turkish F-4 Phantom fighter aircraft avionics systems, navigation systems and electronic warfare capabilities overa period of 5 years.

Israel desired that the problems such as the crises arisen Intervention in Kuwait by Iraq with the leadership of Saddam Hussein, hostile policies toward Israel by the revolution leaders in Iran, and problems of both Turkey and Israel with Syria have to be dealt together with in cooperation of two countries. In short, Turkey would be a friend and ally in the region to save Israel to left alone.

This collaboration with Israel supported and reinforced by the U.S. has played a key role in the develop ment of re lations between the two sides. A U.S. State Department spokesman declared in May 1997,

"It has been a strategic objective of the United States that Turkey and Israel ought to enhance their military cooperation and their political relations". He described the entente as "useful to both countries and the U.S." (10).

By the way, Turkey has gained such a privilege in Congress relying on the influence of Jews where they have suffered at the Greek and Armenian lobby. Jews lobby has helped Turkey to get some weapons system that had been blocked by Congress for human rights reason.

Relationships of both countries improved much more than ever after the co mmemo ration of "Jerusalem Day" sponsored by conservative town council in Ankara on February 2, 1997. Army claiming to make a "balance adjustment to democracy" has sent tanks and armoured carriers to warn against the groups in Sincan, a suburb of the capital of Ankara (11). In the late of February 1997, Ch ief of General Staff, Ismail H. Karadayı paid a first high level visit to Israel. Karadayı praised the good relations in the past between two countries and stated that face to face meeting was the best way to make progress. Following this visit, three important issues achieved; first, joint air and naval exe rcises would be done in 1997-1998, second, mutual intelligence exchange would be realized and finally, Turkey obtained an opportunity to go in the joint production as a partner in Israel defence Industry.

Subsequently, on 8-9 April 1997 Israel Minister of Foreign Affairs visited Ankara; Minister of Defence Turan Tayan paid back the visit to Israel and Deputy Chief of Staff, General Cevik Bir paid a visit on May 4-6 respectively. All those visits ended up with the visit of Israeli Chief of Staff Amnon Lipkin-Shahak. During these visits, a significant participation of senior companion has created the opportunity to meet with each other on both sides.

\subsection{Military-to-military relations}

Due to the fact that territorial claims, water disputes, terroris $m$ are the bleeding wounds between the relations of Turkish Middle Eastern neighbours. Turkey assessed that she needs an ally like Israel to build up deterrent posture in the Middle East through cooperation with Israel to reduce risks likely to develop along Turkey's southern frontiers (12).

In regard to Turkey's perspective, Turkey considered Israel either a high technology sources or a power to provide counter balance to Syria which obviously support Kurdish insurgency. Sükrü Elekdag stated in his article "2 $1 / 2$ war strategy" (13);

"The defence cooperation agreement concluded between Greece and Syria in June 1995 has utmost significance in relation to Turkey's security. The fact that Greece and Syria, both of whom have claims over Turkey's vital interests and territory and support a covert war aiming to break up this country are in a total conformity of interest is indisputable proof that the said cooperation agreement is directed against Turkey...Since 1982 the Syrian govern ment has provided shelter to the PKK, provided it with arms, trained PKK militants and used themagainst Turkey. Syrian officials have helped terrorists infiltrate Turkish territory with their light and heavy weapons."

According to the threat assessment that Syria, PKK and Greece have formed an alliance against Turkey and the only way to counter this block for Turkey was establishing close relations with Israel. In this context Israel was a unique partner to share common values against Syria with Turkey.

On the other hand Israel has its own security needs in geostrategic point of view. Mustafa Kibaroglu stated these requirements as follows:

"While Turkey needs technology, Israel needs space. Israel has nuclear capabilities, and it will soon have a missile shield based on the Arrow. But the deployment of Israel's nuclear arsenal is problematic, and a large-scale ballistic missile attack could penetrate Israel's shield and cause thousands of causalities. Because of Israel's small size, the density of its population, and the concentration of its military facilities, the penetration of air defences by even a single tipped with a chemical, biological, or nuclear warhead could wreak immense damage"

Since Israel has very limited geographic location she needs vast manoeuvring air and sea space to conduct its strategic defence operation. For that reason Turkey is very well tailored to provide Israel such necessities. Thus Israel would come to Turkey using Turkish airspace to conduct pre-emptive, preventive strikes or counter attacks against the target country. The ability to launch attacks from or refuel over Turkey would greatly increase the striking range of Is raeli aircraft. Addition to that training of Israeli pilots in Turkey's airspace would provide them to have sufficient experience of flying over mountainous terrain modelled like potential threat's terrain profile.

The same goes for sea facilities in the event of a crisis, because Israel's territory is so small it needs safe havens for its war lords and vessels in another foreign territory in order to provide strategic depth to sustain a credible and secure following strike capability. Turkey's geostrategic location, what Israel seeks provides precisely all those requirements to her. 
According to M. Kibaroglu; "The basis for this kind of cooperation has already been laid in the bilateral agreements. According to the 1996 agreement of military cooperation, each country can deploy or temporarily station its land, a ir and naval force units in the other country's territory. For this purpose, they can use one another's air space, airports and naval ports".

As an example; in February 1998 Nuzhet Kandemir, Turkey's ambassador to Washington sent messages to Baghdad saying that Turkey would be very sensitive to any Israeli request to fly fighters through Turkish air space to retaliate for Iraqi missile attacks (14). In 6 September 2007, Israel attacked on the Syrian al-Kibar Nuclear Facility (15) fuel tanks used by jets were found on the Turkish soil is the evidence of above mentioned agreement implication.

The main strategic objective of Turkish-Israeli interdependence was to deter war either party and to show solidarity against third party in the Middle East. Actually according to Michael Eisenstadt of the Washington Institute for Near East Policy:

"Turkey would gain little by openly supporting the Israeli war effort, which would make Turkey target for Syrian retribution (i.e. more terroris $\mathrm{m}$ ) and Arab political censure. Turkey is therefore more likely to render assistance to the Israeli war effort quietly, providing intelligence, missile early warning data, and refuge for damaged Israeli a ircraft or warships. In this way, it could help Israel punish a troublesome neighbour and gain the good will of Israeli political and military leaders without incurring major risks".

Post-Gulf war period, after 1991, Turkey gave much more importance to her relations with Israel against the threat of Syria-PKK cooperation.

In this context, an agreement was reached that Turkish $\mathrm{F}$ 16 pilots would be educated about aircraft electronic warfare systems in Israel and in return, Israeli pilots would have an opportunity to fly over vast Anatolian mountainous terrain, for long-range flight training. Eight times a year Israeli pilots would came to Turkey and gain the ability to flight in mountainous profile which is similar in character to Iranian terrain. Turkish pilots would spend time in Israel as well. Moreover, two sides held joint naval and air search and rescue exercise in Mediterranean Sea first in June 1997 and this would be continuous. Exercise done near Syria and then renewed in November 1997 with the participation of U.S.A. could be a message to Syria. In this respect, the Turkish Navy ships from Turkey visited the port of Haifa in July 1997 on the occasion of joint "The Sea-Wolf-97" drill which both countries and the U.S. attended. 30 November to 4 December 1997, "Reliant Mermaid" was an exercise for natural disasters held by triples. All of these exerc is es have been done in order to reveal the power of the Turkey-Israel military cooperation and coordination. In June 2001 Turkey, Israel and the United States planned a joint air defence exerc ise, "Anatolian Eagle" in Konya/Turkey, participating with various 46 aircraft from Turkey, 10 F-16 fighter aircraft from Israel and six F-16 a irc raft and tanker aircraft from U.S. and some various helicopters.
According to Mustafa Kibaroglu "such trilateral military exercises have put in place a mechanis $m$ for advanced military coordination among Turkey, The United States and Israel" Allowing Israel to use of Turkey's air and sea space was reimbursement given by Turkey in return for defence industry cooperation.

\subsection{Turkish- Is raeli defence Industry Cooperation}

\subsubsection{Turkey's Modernization Efforts in Defence Industry after Cold War Era}

The power balance incompatibility in the Middle East revealed by the immediate vicinity of the $1991 \mathrm{Gu}$ lf War put forward by the U.S. drove Turkey's attention to assess the effectiveness of power in her hand. And it was considered that Turkish armed forces update was ess ential in order to be modern and self-suffic ient power on the verge of 21 century. However, the forcing power of this effort was the grant of oldest weapons and supplies to Turkey by the United States and Germany.

Giving extra arms as complimentary aid within the scope of the Agreement on Conventional Armed Forces (CFE) in the Cold War period by the United States contributed an additional assistance besides the arms sales (16).

Within above mentioned period both the Cold War era and the tension with Greece have prevailed, separating by large defence budget share of the general budget of Turkey is seen to strive. Upon the dissolution of the Soviet Union between 1990-1991 with the destruction of the Warsaw Pact and the disappearance of red threat Turkey has taken new decisions in structuring her own national defence industry.

One of the biggest factors in this attempt at modernization was that, with the end of the Cold War, NATO European members frequently expressed that Turkey had not any importance for Western anymore and Turkey needs NATO rather than NATO needs Turkey from now on. As a result, Turkey felt herself left alone by NATO members in Europe and in the light of NATO-free re-evaluation, Turkey assessed her position in regard to her geopolitics and geostrategic aspects in the region. Consequently, Turkey in a geographical region is considered the centre of the new world order, realized the fact that she could be affective as a regional power in the Balkans, the Middle East, Caucasus and Central Asian regions. Accordingly, she tried to build up a modern and self-sufficient and effective armed forces compatible with, but independent of NATO.

In 1996 Turkey officially announced that she would implement the modernization program in armed forces. Updating old systems and the creation of a structure consisting of high-tech weapons and equipment procurement accounted for mainly target for Turkey. As the main objective of a long-term political-military strategy for the program, it was considered the separation initially $\$ 25-30$ billion for the first 8-10 years from the budget share and $\$ 150$ billion 30-year term. Crises from time to time cause problems in applications, although we see the continuation of these modernization activities (17). 
After 1999 the United States has cancelled a grant or credit sales to the countries as Greece and Turkey with relatively good shape economies.

When Turkey, within the scope of the modernization program, demanded to purchase NATO-compatible modern weapons and equipment across the U.S. and western countries, democracy, human rights and rule of law issues came as prerequisite or preventive factors by the West in sales. Arms sales to Turkey posed a problem in the inner dynamics of western producer countries. Opponents and human rights defenders of these countries brought up the issues of incompatibility of democratic and human rights violations so that try to prevent arms transfers. Armen ian and Cyprus issues were another pretext against Turkey to hinder the sales. Defence industry lobbies of them on the other hand did not want to miss a large market share (18).

During this period, especially the Greek and Armenian lobbies in the U.S. have worked effectively by exploiting three important points (19);

- Claimed that Turkey does not meet criteria for arms sales. Issues such as respect for human rights and rule of law are far from democratic Turkey, which is expressed in fluffy criminal file, tried to prevent sales.

- Suggested that the weapons purchased used on its own civilian population. This point in particular has been attempted to be used effectively the purchase of 145 attack helicopter worth $\$ 4$ billion during the President Clinton period, 1996-1997 (20). U.S. arms sales suspended initially, but afterwards slowed implementation of a two-year period were chosen.

- It is said that Equipped with modern weapons to the Turkish Armed Forces are against the country's democracy. A strong army with modern weapons are claimed to exert a more powerful mechanis $m$ of the intervention in internal politics. The effect of the military in politics in modern democracies is not considered. Therefore, with such an approach it was trying to create an argument against the democratization of Turkey.

Meanwhile, such claims have provided some particular advantages to the manufacturers of these countries against Turkey. It can be said that U.S. and Western governments tried to protect their high price sale strategies until the last moment using of those claims as tru mp cards. In the face of additional demands like technology transfer and joint production, saying that "we are already working hard to supply, under this circumstance we are not able to deal with your demands". And, they used this pretext to steer sales in accordance with their own desires.

In 1999, it has been attempted for the purchase of Leopard tanks from Germany. The country, dealing with unemployment on the one hand struggling to abstain from the sale on the grounds of human rights violations in Turkey, while the input from the other side of the country of the sale of these tanks have been on the horns of a dilemma. In fact, five or six billion dollars a thousand tanks would provide a value equal to Germany's three-year foreign military sales
(21).

Consequently, all these developments have led Turkey the formation of a lack of confidence to the west on the basis of establishing its national defence industry.

\subsubsection{Turkey is in Russian and Chinese Markets}

Turkey, in the face of these negative outputs of the West has been in search of available resources especially to provide weapons and equipment to use against terrorism. Russia, imposing any reservation to what end is going to use of the weapons and equipment was the first stop. And relations with Russia have been developed to advance. These sales provided relief to Russia, which is a rather difficult position in terms of financing in the 1990s. Meanwhile, to take part in the international arms market China was trying to develop a new strategy. China's positive approach to missile technology transfer and joint production has been an important factor in causing the relationship with this country. However, Russia's technology and system designs were outside of NATO standards have led to this country on the needs of limited purchases. Russia already has chosen to continue the relationship by being aware of th is is sue.

The first five years following the end of the Cold War international arms market contracted by more than $30 \%$. This structuring of the defence industry and the existing institutions of the countries affected by recession, and many has turned to foreign purchases. Turkey has taken its share of this trouble. Ranking of world arms spending in the second half of the 1990s Turkey has taken place within the top ten in the list. Due to scheduling compatible with NATO weapons and equipment, Russia and China have to be left out of the market in conventional arms by Turkey. In connection with the fight against the PKK terrorist organization BTR armoured vehicles, MI-8 and MI-17 helicopters were purchased from Russia in 1993-1995. Cooperation in missile technology to China was for the joint production in 1998-2007 (22).

The Russian-Turkish military technology cooperation developing since 1993, resulted in purchase of 70 BTR-80 armoured personnel carriers, a number weapon intake and 19 Mi-17 (Hip H) helicopters worth \$ 114 million in 1994 (23). Turkey has made payments in cash through Turk Eximbank to Russian Vnesheconombank. On these developments, the Turkish Air and Naval Forces have made a request to purchase of various weapons systems from Russia. M-28 (Havoc) and Ka-50 (Hokum) helicopters, airborne missiles, amphibious landing ships, and Project 636 (Kilo class) submarines are examples of them. Dealing with the Russian state arms sales firm "Rosvoorouzhenie" has proposed to Turkey to sale frigates, missile patrol boats, MiG-29 (Fulcrum) Co mbat Aircraft, S-300 air defence system, T-80 tanks, and helicopters Ka-50. However, because of the cooled relations due to differences of opinion about the Straits, and Chechnya these offers could not be realized.

According to the evaluations of Russia's State Committee for Military-Technical Policy (SCMTC), Turkey has never 
bound itself with a large-scale purchase from Russia. The core of these Turkish initiatives lies in to gain convenience on price or delivery by showing an alternative to the west. In this regard, a wide range of defence cooperation with Russia is not possible to enter. An example was giving that Turkey's reversal the Russian proposal to produce of Kalashnikov machine guns in the Turkish defence industry facilities, under NATO standard in 1997 (23).

Another concern is to prevent the provision of the rule of the Turkish Navy in the Black Sea. For this reason, Russia gave up the idea of making transfers to Turkey, frigates, weapons systems and related technology such as guided missiles against surface ships, anti-aircraft missile systems stationed on board etc.

By the late 1990s, Turkey has come up again. Russia has made a very attractive offer in Turkish helicopter tender. According to the proposal, Turkey, produced Ka-50 helicopters under the license of Russia would be allowed to export independently. This is a privilege previously granted to any country. In addition, a particular party of helicopters would be given by Russia for a debt of $\$ 300$ million. Market value of helicopters in the world price by more than $50 \%$ discount, $\$ 13$ million has been provided as another surprise bid. The most important benefit of all this was that Russia agreed to transfer technology to Turkey. In this case, Turkey would have desired high technology, and her national facilities would gain the ability to produce and develop domestically. However, these initiatives did not find the possibility of NATO member Turkey in terms of standards.

\subsubsection{Israeli Cooperation with Turkey in Defence Industry}

On August 1996 an agreement made on cooperation in the defence industry which ties Turkey and Israel were given a major boost (24). Meanwhile, in 1996 the agreements made with Israel provided a certain relief in Turkey. The west which put various challenges of military sales to Turkey on the pretext of human rights violations has been taking the secondary position. The first two deals with Israel in 1996 were valued about $\$ 800$ million modernization of F-16 aircraft and missile production. This figure was 500-600 million dollars in annual exports of weapons and equipment, and with relatively small makes, a big step for the Israeli defence industry.

Within the first half of 1990's Turkey evaluated Israel as a most convenient resource which has most sophisticated high technology production capabilities as well as U.S. and NATO standards. Moreover, Israel seemed to accept Turkey's request for joint production and technology transfer. She was also eager to contribute to develop of newly established Turkish national defence companies and to accept to work as a sub-contractor under the Turkish firms as well. It was a great opportunity for Turkey that Israel willing to cooperate with and educate the Turkish engineers in every aspect of the defence industry issues.

As a result, even if not disclosed to public, together with all agreements, the decisions have been taken formally to be in collaboration with the following subjects on defence industries either in joint productions or technology transfers (25).

Modernization and upgrading of weapon systems: Agreement within the scope of the defence industry, the largest a mount of worth of $\$ 632.5$ million were made in the modernization of 54 F-4E Phantom aircraft. It was envisioned to enhance the high firing and manoeuvring capabilities and to gain better electronic warfare and vision skills to all fighter planes called Phantom 2000. In order to perform this agreement, almost all of the value of this agreement has been provided by Israel as credit. Another agreement has taken its place as $\$ 75$ million worth of $48 \mathrm{~F} 5$ modernizations within a consortium of Israel-Singapore. M-60 tanks upgrading in the version of Merkava III worth of $\$ 50$ million within jo int venture was another important issue between two countries.

Weapons Systems purchasing: So me weapon systems such as Popeye I missiles were purchased separately in the context of Phantom project. Moreover, Turkey has made clear interested in Arrow missile defence systems, Falkon early- warn ing aircraft systems, radar systems for detecting conventional and plastic mines. In addition; demanding ground radar systems to seal off the Turkish border on Syria and Iraqi to prevent infiltrations; unmanned aerial vehicles; maritime patrol aircraft and $\$ 800$ million worth of AWACS early warning aircraft were other items. Israel wanted to sell $\$ 5$ billion worth of 1000 Merkava III main battle tanks to Turkey (3) (26).

O Joint Production: Both countries have reached an agreement to invest $\$ 150$ million to produce hundreds of Popeye I and II missiles and run in with the project Deliah long-range missiles.

\subsection{Intelligence Sharing}

Both countries have agreed to share information which poses the threats from others (10). Israel's Pilot training activities in Turkey was providing assistance to gather information about Iran, Iraq and Syria. In addition, It is expressed that Israel has provided to Turkey some information dealing with the PKK (27)and technical intelligence about MiG-29 fighter planes which Syria own. Syria and even Iran bothered about the fact that Turkish-Israeli military cooperation has brought Israel to its border in the form of intelligence and $\mathrm{C} 3$ listening posts on Turkish soil. Moreover; relation with Israel has strategic value for Turkish military because of Syrian support to Kurdish insurgents (28).

It seemed that Israel was ready to make all contribution to cover Turkey's shortages with its vast intelligence network. In return for all of these contributions, Is rael was demanding help from Turkey to preserve the balance of stability in the Middle East issue.

\section{What Changed?}

As a real politics nothing changed concerning Is rael policy toward Turkey. But in regard to Turkey "that's water under 
bridge" after 2007 election that AKP a warded second term in government. We can examine within three headings to figure out what has changed in Israeli politics in Turkey as of then.

First, one of the most striking regional developments of 2009 has been the re-emergence of Turkey as a major player within the greater Middle East. A new doctrine, known as the Strategic Depth doctrine, Ahmet Davutoglu has utilized to guide the fore ign policy of AKP government (29). In its book titled "Strategic Depth" (6)he argues, first of all, that Turkey lies at the heart of three geographical areas of influence and should formulate a foreign policy accordingly, calls for an activist engagement with all reg ional systems in the Tu rkey's neighbourhood, including the establishment of strategic relations with the Middle East, the Caucasus, Russia and Central Asia (30). Secondly, Erdogan's foreign policy under the guidance of Davutoglu should pursue a policy of "a zero conflict" and "Maximum Engagement" with its neighbours, as well as a balance between relations with Europe, the Middle East, Asia, and with the United States, mainly by improving economic ties. Ahmet Davutoglu, a professor of international relations, who served as a special adviser to Turkey's Prime Minister Recep T. Erdogan before being appointed as Turkey's Foreign Minister in 01 May 2009 is main architecture of Turkey's new policy called "zero problem with neighbours".

In his book Davutoglu brings new point of view on Turkish-Israeli relations and stated that;

"From now on, Turkey has left the image of the passive side in the relations with Israel. She faces with the need of a new assessment on these relations within the framework of inter-regional interaction areas and overall Middle East policy. Conversion ofbilateral tactical relations into strategic axis without inclusive strategies for improvement set out in the whole region creates inevitable restrictive results in dynamic international conjuncture. Today, developments in the Middle East provide to Turkey much more opportunity than ever to become more efficient".

Minister of Foreign Affairs A. Davutoglu purely put Turkey's foreign policy in the region with his article sent to Foreign Policy Magazine in 20 May 2010 (31); “To achieve them, Turkey must make progress in all directions and in every field, take an interest in every issue related to global stability, and contribute accordingly. This collective effort will make Turkey a global actor in this century. Turkey's actions are motivated by a great sense of responsibility, entrusted to it by its rich historical and geographic heritage, and by a profound consciousness of the importance of global stability and peace"

Addition to that policy, vision of foreign policy has changed. Old foreign policy approach was indexed to internal challenges such as Islamis m and Kurdish separatism just like Ian O. Lesserstated in artic le "Turkey in a Changing Security Environment; It is important to note that Turkey's security policy elites consistently place internal challenges, including Islamism and Kurdish separatism, at the top of their agenda. In the context the discourse over these issues in the security debate interacts with their perception of the external security environment, particularly in relation to the Middle East" (32) (33).Leaded by Ahmet Davutoglu, vision of Turkey has changed radically just as stated as follow; (31); "...The first methodological principle is its "visionary" approach to the is sues instead of the "crisis-oriented" attitude that dominated foreign policy during the entire Cold War period. For example, Turkey has a vision of the Middle East. This vision encompasses the entire region: It cannot be reduced to the struggle against the PKK (Kurd istan Workers' Party), the radical Kurd ish separatist group that for decades has waged a campaign of terror against Turkey, or efforts to counterbalance specific countries. Turkey can use its unique understanding of the Middle East, and its diplomatic assets, to operate effectively on the ground. Turkey's Lebanon policy, its attempts to mediate between Syria and Israel and achieve Palestinian reconciliation, its efforts to facilitate the participation of Iraqi Sunni groups in the 2005 parliamentary elections, and its constructive involvement in the Iranian nuclear issue are integral parts of Turkey's foreign-policy vision for the Middle East". That means Turkey has taken completely different attitude in Kurdish issue considering it as internal affairs and focusing much wider spectrum in international affairs especially in the Middle East. This is also reducing Israel's intelligence contribution to PKK issue.

Indeed above mentioned is a clear signal that Turkey would diversify its policy of Israel in a particular time frame according to new regional policy adapted by Justice and Develop ment Party government.

Second, In March 2009, Turkey's then Min ister of Fore ign Affairs Ali Babacan announced in an interview that new elected U.S. President Barack Obama had opened a 'new era' in relations between the two countries (34). President Barack Obama paid a visit to Turkey in 6 April 2009 and addressed in Parliament saying that "the future must belong to those who create, not those who destroy. That is the future we must work for, and we must work for it together now" (35)and gave a great deal of confidence to Prime Minister Erdogan's government. Misunderstanding arising in U.S. invasion of Iraq in 2003 in President Bush admin istration Turkish new elected government for eight years recovered by this visit. Due to Turkey's opposition of the American invasion of Iraq and its parliament refused to pass a 2003 motion that would have allowed A merican troops to enter Iraq through Turkish soil.

The United States, meanwhile, had at this time been uncomfortable with Turkey's active re-engagement with the Middle East, particularly its growing relations with Syria and Iran. President Barack Obama has been looking to Turkey as "a model partner" to help improve U.S. relations with the Middle East and wider Islamic world (36). According to President Obama's policy Turkey can play quite a strong role in the region, and more general support in the Middle East.

Due to the fact that Turkey is one of the few countries that talks to everybody in the Middle East, from Tel Aviv to Teheran, from Damascus to Bagdad. And she is able to talk to Hamas etc. (37).President Obama put particular emphas is to Turkey's role in the Middle East as a reg ion in which the 
United States needs to be in cooperation with. The United States needed Turkey for help in its planned withdrawal from Iraq, and for its build-up of troops in Afghanistan. Ankara's improved relations with Syria and Iran, mean while, could be helpful for the Obama administration to establish a dialogue with those two countries. Energy security and the development of new routes for delivering oil and gas to western markets are issues that could also benefit from Turkish-American cooperation, experts say (38).So although Turkey were not the main decision maker in the Middle East, she undertook the position that help in conveying messages and in passing messages back to Obama ad min istration.

In this context Prime Min ister Erdogan assessed that his government Middle East policy is in right direction in comply with the concept of "zero problem" with neighbours such as Iraq, Iran and Syria. Gradually cutting relations with Israel was Turkey's last move to persuade the Arab states. For that reason Erdogan's government felt itself immune because of sufficient support from U.S. President Barack Obama directly. In parallel with this refreshed political relation between two countries, intelligent sharing on the subject of terrorism that Turkey suffered was renewed and strengthened, since 2007 was in force. Real-time intelligence sharing between the U.S. and Turkey in order to supply critical information about PKK movements to the Turkish military was formally agreed upon by Prime Minister Erdogan and former U.S. President George W. Bush in 2007 (39). In his address to the Grand National Assembly, President Barack Obama confirmed that the US would continue to support Turkey "against the terrorist activities of the PKK". The cooperation between the Turkish and US military authorities could thus be expected to continue (34). Thus the importance of the intelligent that Turkey received from Israel since 1996 were diminished (40). The close cooperation re-established by new U.S. president paved the way to Erdogan's government that could criticize loudly Israel's disproportionate attack to Gaza Strip ignoring all dependencies in the early 2009.

Third, today Turkey has its own defence industry infrastructures and various companies which took their own place in the world order such as Aselsan, TAI and Havelsan. Compering to the initial period of the establishment, now Turkey has its own intellectual capitals in defence industries as well as engineers and other technicians. Moreover, those companies are able to design their own national productions and programming embedded software particularly in weapons systems. Thus, Turkey feels herself much less depended to Israeli cooperation and technology transfer. For example; today companies such as Aselsan developed payloads through a research and development shame and participated Israel's Heron Unmanned Aerial Vehicles (UA V's) project as a sub-contractor. But Israel put some difficulties to use payloads developed by Aselsan. This problem was not a new event according to the Turkish defence industrialists. Despite the fact that Israel offered transfer of high-technology military assets but most of the case failed to honour its commitments and refused to transfer certain critical technologies to Turkey in projects contracted to Israeli companies that made a source of frustration in Turkish defence sector (41). However, the frustration came up with the unilateral "fait accompli" by Israel led Ankara crisis of confidence. This is probably another negative factor that affects the deterioration of relations. Moreover, in 2010's Turkey is proud of her to have its own national defence industry sectors and feels free from connecting to Israel's contribution any more even she knows her weakness and shortages. In particular Aselsan has been replaced among the world top 100 companies in the defence industry (42).Turkey these days rose to a position of defense industry that exports products to 143 countries. Turkey's export of 400 million dollars last year increased the first three months of this year by $45 \%$ (43).

\section{Conclusions}

The first unrest between Turkey and Israel has emerged with Israel's Gaza operation in December 2008 and January 2009. When Israel attacked Gaza left around 1400 dead, a large percentage of ruins and a humanitarian crisis in its wake. The world was outraged by Israel's disproportionate and unnecessary use of force. Turkey condemned Israel's actions (27). Although this problem reveals itself in the political arena and reach a low point as a result of Israel's offensive along with three weeks in the Gaza-Strip but in the military relations could not find an echo. Although strong criticis $m$ of Turkish political authorities against Is rael's operation in Gaza, Turkey did not take any position to retaliate by suspending or cancelling arms procurement projects value of million dollars or its military cooperation with Israel. Even ups and downs could be seen in the political relationships between Turkey and Israel; military ties were not expected to be affected due to the depth of mutual national interests of these relationships (44). In the press conference government spokesperson and Deputy Prime Minister Cemil Cicek made it clear that Ankara was not considering retaliation against Israel through suspending the countries' military relationship or cancelling a recent project agreement signed with Israel. Almost a day before Israel responded to Hamas rocket attacks, which broke the six-month-long truce, Turkey and Israel rather quietly signed an arms cooperation deal. The Turkish public became aware of this deal when an announcement was made by the Israeli side (44).

Israel Aerospace Industries Ltd. and Elbit Systems Ltd. announced that their respective subsidiaries have been awarded a $\$ 141$ million contract $\$ 87$ million awarded to Elbit Systems Electro-Optics and \$54 million awarded to ELTA) to supply the Turkish Air Force with combined airborne IMINT (imagery intelligence) systems (45). The remain ing \$24 million will be Turkish Aselsan's share as the main contractor in the project, bringing the total cost of the project to $\$ 165$ million (46). The imagery intelligence systems are developed for unmanned aerial vehicle (UA V) 
payloads and fighter aircraft pods, as well as SAR systems for business jets. Many systems are used for comprehensive intelligence, surveillance and reconnaissance applications, said the Is raeli companies' statement. The project will enable the Turkish Air Force to gain an important capability in intelligence gathering in its pursuit of the outlawed Kurdistan Workers' Party (PKK) (44).

The abovementioned figures alone display the importance of ties between Turkey and Israel in military and procurement relations, which do not seem to be affected seriously by the on-and-off political disagreements between the two (44).

Turkey's one another jo int projects value of $\$ 687.5$ million with Israel was Israeli modernization of 170 M60A1 main battle tanks in Turkey's inventory. Israel Military Industries (IMI) has delivered the last of 170 upgraded M-60A1 tanks to the Turkish Army. April 7, 2010, at an official ceremony held at Kayseri, Turkey. Israel Military Industries (IMI) is the prime contractor for the program and Aselsan and MKE fro $\mathrm{m}$ Turkey which operated alongside IMI to facilitate local support for the systems (47).

Turkey also purchased from Israel 10 UA V systems, and the first six UAV aircraft ordered from Israel were delivered to Turkey in March 2010 following a delay of over two years. The remain ing four delivered in September 2010 (48). The UA V systems cost about $\$ 183$ million. The expected arrival of the Heron drones to Turkey comes in the midst of on-going tension between Turkey and Israel, which came close to a breaking point on May 312010 when Israeli commandoes killed eight Turkish citizens and one American aboard a humanitarian aid ship (46).

While military relations efforts be continued in this way, it is not possible to say the same thing in political relations. In any case, the military in Turkey was used to be the key promoter of relations with Israel. Concerning the bilateral military cooperation and joint ventures in defence were unlikely to continue due to the government political approach toward Israel after Gaza bombardment (2). There has been a steady deterioration in the previously close political relationship between Turkey and Israel even in military sides did not put in the same vision.

It seems that the Turkish defense industry has not yet come namely to be self-sufficient to accomplish what it set out to do when it signed defense industry cooperation agreement with Israel on 28 November 1996 (14). Erdogan's government has taken some risks in favour of new foreign policy in the Middle East despite of the such shortages in the defense industry.

Justice and Development Party awarded second term in 2007 election as a government with more confidence and spent an effort to apply its own foreign policy strategy in the Middle East was just designed by A. Davutoglu who was appointed as the Minister of Foreign Affairs in May 2008. Within the framework of new architecture of Recep T. Erdogan's government foreign policy Israel's Operation Cast Lead in Gaza Strip incident and subsequent public confrontation in Davos a few weeks later between Prime
Minister Recep T. Erdogan of Turkey and President Simon Peres of Israel were just pretext not the real reasons for the regenerating or deteriorating relations with Israel (49). In October 2009 Turkey eventually cancelled Israel's participation to "Anatolian Eagle" mult inational a ir exercise and following harsh criticis $m$ of Turkish leaderships of Israeli policies towards Palestinian issue. And finally relations hit on the rocks with the "flotilla crisis" of May 2010. All those evens happened more or less at the same period of time encountered to the date of U.S. President Barack Obama's visit to Ankara which opened "a golden age of two countries relations" (50).

Because Turkish government's new policy under AKP stated like Karen Kaya "which required engagement with its Arab neighbours, necessitated a more vocal criticism of Israel and a more sensitive tone to the Palestinian issue. Thus engaging all parties in the region, bolster Turkey's economic prospects and create a zone of economic integrations and regional stability. As a result, Ankara engaged all its neighbours, including Syria and Iran. Ankara managed to bring Israel and Syria to the table for proxy negotiations. And, she offered to mediate between U.S. and Iran on nuclear matters. Basically, AKP's new foreign policy of "zero problems with our neighbours" was driven tool towards the goal of regional leader in the Middle East and playing an important role as a mediator in some of the region's toughest conflicts" (4). In this context, Turkey made a security cooperation agreement with Syria and Iran. This was completely reversal of the security context of the 1990's requirements, when Turkey established a close cooperation to defend against the strategic alliance between Iran and Syria which was supporting Kurdish insurgency. Thus both countries status have been elevated from threat to strategic and close friends (28).

At this point, Turkey declared that the normalization of relations required Israel to issue a formal apology, pay compensation to the victims' families, and lift the blockade on Gaza. But Israel refused to apologise and lift ing blockade on Gaza and as a retaliation Turkey was "totally suspending" all trade, military and defence industry ties with Israel and downgraded diplomatic relations to the level of second secretary.

When evaluating the winner and loser, the result by cutting military relations between two countries obviously cannot be determined in a sound manner. Initially, a "win-win" relationship which was established as (51) highlighted the situation is as follows; following the rejection of Turkey's demands by Israel, Turkey has suspended the enforcement of all military and defence industry agreements as sanctions which brought a vision that Israel was lucrative. But, in terms of its national interests Israel lost its strategic advantages to use Turkey's air space, airports and naval ports to compensate its lack of territorial depth which would be a painful headache in future. In this regard, rational solution seems in the form of apology and compensation to be accepted by Israel even it seems Israel is losing. 
As a result, while Turkey has lost advantages such as purchasing of high technology weapon systems and joint production, technology transfer and intelligent sharing opportunities in cooperation with Israel, in return, Israel has lost the advantages in terms of security needs which is vital for him to meet the strategic requirements.

Afterwards the tensions with Israel, abruptly emerging of the Arab Spring embedding Israel silent, has caused that Turkey find itself enjoying as a regional power in cooperation with the U.S. in North Africa and the Middle East.

As a last word, the second term of government AKP has decided to change its foreign policy in comply with the A. Davutoglu's concept of "zero problem with neighbours". And it determined to open its hand to negotiate with the Middle Eastern countries, Syria, Egypt, Iran and Iraq on the problems which remained on the table. U.S. President Barack Obama visit paved the way to encourage Ankara applying this pro-active policy toward old-hostile Arab countries ignoring Israel sensitivity. For this purpose Prime Minister Recep T. Erdoğan has taken tough position on the occasion emerged with Israel Gazza attack.

\section{REFERENCES}

[1] Migdalovitz, Carol. Israel's Blockade of Gaza, the Mavi Marmara. Washington : Congressional Research Service, 2010 June 23

[2] Turkey and Israel. Eran, Oded. 2010, INSS, pp. 109-117.

[3] Pipes, Daniel. A New Axis the Emerging Turkish- İsraeli Entente. National İnterest.[Online] 1997/1998.[Cited: March 22, 2012.] http://www.danielp ipes.org/293/a-new-axis-the-e merging-turkish-israeli-entente, "A New Axis th.

[4] Kaya, Karen. Changign trends in Israel-Turkey Security and Military Relations: Their Perspectives. Fort Leavenworth : FMSO, January 2011.

[5] Turkish-Israeli Relations Through the Lens of the Turkish Identity Debate. Yavuz, Hakan M. Autumn 1997, Journal, pp. 24, Vol XXVII, No.1, Issue 105.

[6] Davutoglu, Ahmet. Stratejik Derinlik (Strategic Depth). Istanbul : Kure Yay inları, December 2008. p. 426.

[7] Turkish-Israeli Relations in a Trans-Atlantic Context:Wider Europe and the Greater Middle East. Susser, Bruce Maddy-Weitzman and Asher. Tel Aviv : The Moshe Dayan Center for Middle Eastern and African Studies, Tel Aviv University, 2005.pp. 53, 56.

[8] The Fanthom Alliance. Blanche, Ed. 10 March 1999, Jane's Defense Weekly, pp. Vol. 31, No.10.

[9] Smith, Randy J. The Pragmatic Entente: Turkey's growing relations with Israel. Thesis. January 2000.

[10] Turkey and Israel :A New Balance of Power in the Middle East. Waxman, Dov. 1999, The Washington Quarterly, p. 31.

[11] Meliha Benli Altunışık and Özlem Tür. Turkey: Challenges of Continuity and Change. NewYork : Routledge Curzon,
2005. p. 59.

[12] Kibaroğlu, Mustafa. Turkey and Israel Strategize. Middle East Qarterly. Winter 2012,pp. Vol. IX No. 161-65.

[13] 2 1/2 War Strategy. Elekdag, Sukru. 1996, Perception Journal of International Affairs, pp. 33-57.

[14] Cooperation in the Israeli-Turkish Defence Industry. Kogan, Eugene. September 2005, Conflict Studies Research Center, pp. 1-24.

[15] Goodman, Daveed Gartenstein-Ross and Joshua D. The Attack on Syria's al-Kibar Nuclear Facility. inFocus Quarterly. Spring Vol III No 1, 2009.

[16] U.S. Military Aid and Arms Sales to Turkey, Fiscal Years (1980-1999). www.fas.org.[Online] http://www.fas.org/ asmp/profiles/turkey_fmschart.htm.

[17] Hen-Tov, Eliot. The Political Economy of Turkish Modernization. Meria.idc.ac.il.[Online] 2004.[Cited: March 17, 2012.] meria.idc.ac.il/journa1/2004/.../hentov.pdf.

[18] A Triangular Relationship Turkish Israeli Cooperation and its İmplications for Greece. Nachmani, Amikam. 1999, Cahiers d'etudes sur la Mediterranee orientale et le monde turco-iranien, pp. 1-15.

[19] Turkey, Arms and Human Rights. Gabelnick, Tamar. May 1999, Foreign Policy Focus, p. 1.

[20] Tamar Gabelnick, William D. Hartung and Jennifer Washburn. Arming Repression: U.S. Arms Sales to Turkey During the Clinton Administration. www.fas.org.[Online] ctober 1999.[Cit ed: March 19, 2012.], http://www.fas.org/ asmp/library/reports/turkey rep.htm.

[21] WMEAT, Table II. Arms Transfer Deliveries and Total Trade, (1989-1999), By Region, Organization, and Country. WMEAT.[Online] 2000.[Cited: March 19, 2012.]. http:// www.state.gov/t/vci/rls/rpt/wmeat/1999_2000/.

[22] SIPRI Arms Transfers Database, "Transfers of major conventional weapons: sorted by recipient. Deals with deliveries or orders made for year range 1990 to 2009. SIPRI 2010.[Online] April 25, 2010.[Cited: Aralik 17, 2011.] www.sipri.org/research/armaments/transfers/.../Recipient-20 06-2010....

[23] Sergei Kandaurov. Russian Arms Exports to Greece, Cyprus and Turkey. Moscow Defense Review.[Online] February 2001.[Cited: March 21, 2012.] http://mdb.cast.ru/mdb /2-2001/at/raegct/.

[24] Jenkins, Gareth. Israel's Barak in Ankara to Try to boost Defense Ties. Eurasia Daily Monitor. February 13, 2008, p. 1.

[25] The Remarkable Turkish-Israeli Tie. Nachmani, Amikam. June 1998, Middle East Quarterly, pp. 19-29.

[26] Müftüler-Bac, Meltem. Turkey and Israel: An Evolving Partnership. Turkey : ACPR olicy Paper No. 47, 1998.

[27] Factsheet: Turkish-Israeli relations. Canada : CJPME, 2010.

[28] The crisis in Turkish- Israeli relations: What is its strategic significance? Kosebalaban, Hasan. 2012, Middle East Policy Coincil, pp. 1-13.

[29] Murinson, Alexander. The strategic depth doctrine of Turkish 
foreign policy. Middle Eastern Studies. November 2006, Vol. 42, 6, pp. 945-964.

[30] Speetjens, Peter. New Turks with "Zero Problems". Executive issue .[Online] December 2009.[Cited: May 01, 2012.] http://www.executive-magazine.com/ getarticle.php? article $=12522$.

[31] Turkey's Zero-Problems Foreign Policy. Davutoglu, Ahmet. 201020 May, Foreign Policy Magazine, pp. 1-9.

[32] Turkey in a changing security environment . Lesser, Ian O. 2000, Journal of International Affairs, p. 185.

[33] The limits of an alliance: Turkish-Israeli relations revisited. Bacık, Gokhan. 2001, Arab Studies Quarterly, pp. 49-63.

[34] Turkey and the Middle East in the 'New Era'. Hale, William. 2009, Insight Turkey Vol. 11 / No. 3 , pp. 143-159.

[35] Remarks by President Obama to the Turkish Parliament http://www.whitehouse.gov.[Online] April 06, 2009.[Cited: May 01, 2012.] http://www.whitehouse.gov/the_press_office /Remarks-By-President-Obama-To-The-Turkish-Parliament.

[36] Aliriza, Bulent. The Turkish-Israeli crisis and U.S-Turkish relations. washington: Center for Strategic and International Studies, 2011.

[37] Shapiro, Ari. Obama's Visit Benefits U.S., Turkey. NPR.org.[Online] April 07, 2009.[Cited: May 01, 2012.] http://

www.npr.org/templates/story/story php?story Id=102821473.

[38] Schleifer, Yigal. Turkey: Obama Visit Sparks Hope of Reinvigorated US-Turkish Strategic Partnership. Eurosia insight.[Online] April 02, 2009.[Cited: May 01, 2012.] http://www.eurasianet.org/departments/insight/articles/eav04 0309a.shtml.

[39] US reconnaissance plane supplying Turkey with intelligence. Tanis, Tolga. 2011, Savunma ve Stratejik Analizler, pp. $\mathrm{http}: / /$ www.hurriy etdaily news.com/n.php?n=u.s.-reconnaissa nce-plane-supply ing-turkey-with-intelligen ce-about-pkk-mo vements-2011-05-13.

[40] Onarlı, Barış. Riccierdone: İstihbarat Paylaşımı 'Kesinlikle Devam Edecek'. Voice of America VOA.[Online] November 03, 2011.[Cited: April 04, 2012.] www.voanews.com/ turkish/news/Ricciardone-stihbarat-Pay lam-Kesinlikle-Deva m-Edecek-133165873.html.

[41] Turkey's ilitary Procurement Dilemma with Israel. Sariimrahimoğlu, Lale. 2009, Eurasia Daily Monitor, The Jaqmestown Foundation, p. Vol 6 İssue 99.

[42] Aselsan Elektronik Sanayi ve Ticaret A.Ș.,. Aselsan.[Online][Cited: Mart 21, 2012.] http://www.tskgv. org.tr/tskgv/?page_id=22.

[43] Çelik, Önder. Savunma sanayii atağa geçti. Taraf Gazetesi (Newspaper). Istanbul, Turkey : Taraf, April 04, 2012.
[44] Saribrahimoğlu, Lale. Gaza Attack Won't Affect Turkish -İsraeli Military Relation. Today's Zaman. Istanbul : Zaman Newspaper, Aralik 31, 2008.

[45] IAI+Elbit Produce IMINTs For Turkey. Satnews.com. [Online] December 29, 2008.[Cited: April 22, 2012.] http://www.satnews.com/cgi-bin/story.cgi?number=1843511 206.

[46] Sariibrahimoglu, Lale. Turkey's Military Procurement Dilemma with Israel. Eurasia Daily Monitor Volume: 6 Issue: 99.[Online] May 22, 2009 .[Cited: April 22, 2012.] http ://www.jamestown.org/single/?no_cache $=1 \&$ tx_ttnews $\%$ 5Btt_news\%5D=35028.

[47] IMI Delivers the last of 170 Upgraded M-60A1 to the Turkish Army. Defense Update .[Online] March 2010.[Cited: April 22, 2012.] defense-update.com/newscast/0410/armorn ews 0410.html.

[48] Aydıntaşbaş, Aslı. İsrail, Heronları sessizce teslim etti. milliyet.com.tr.[Online] Eylül 02, 2010.[Cited: Mart 24, 2012.] http://siy aset.milliy et.com.tr/israil-heron lari-sessizceteslim-etti/asli-ay dintasbas/siy aset/siy asety azardetay/02.09.2 010/1283956/default.htm.

[49] Rubin, Barry. Turkish-Israeli Relation in the Shadow of Arab Spring.[Online] April 15, 2012.[Cited: May 03, 2012.] http://www.gloria-center.org/2012/04/turkish-israeli-relation s-in-the-shadow-of-the-arab-spring/.

[50] Zaman, Amberin. Turkey and Obama: A Golden Age in Turkish U.S. Ties? The German Marshal Fund of the U.S.[Online] March 20, 2009.[Cited: May 03, 2012.] http://www.gmfus.org/archives/turkey-and-obama-a-goldenage-in-turkish-u-s-ties.

[51] Kibaroğlu, Mustafa. Turkish-Israeli Relations: Past, Present and Future. Belfer Center for Science and International Affairs,. s.l., USA : HARVARD UNIVERSITY, December 12,2004

[52] Deutsch, Karl W. The Analysis of International Relations. New Jersey : Englewood Cliffs, New Jersey: Prentice Hall International Inc, 1988. p. 125.

[53] Gabelnick, Tamar. Turkey: Arms and Human Rights. Foreign Policy Focus.[Online] March 01, 1999.[Cited: 03 17, 2012.] http://www.fpif.org/reports/turkey_arms_and_human_rights.

[54] Turkey Defense Spending, The Library of Congress Studies. CIA World Fackbook.[Online] March 06, 2012.[Cited: March 17, 2012.] https://www.cia.gov/library/publications/th e-world-factbook/geos/tu.html.

[55] BBC News Europe. Turkey suspends Israel defence ties over Gaza aid raid. BBC News.[Online] September 06, 2011.[Cited: April 04, 2012.] http://www.bbc.co.uk.

[56] Turkey suspends Israel defence ties over Gaza aid raid. BBC News.[Online] September 06, 2011.[Cited: April 04, 2012.] http://www.bbc.co.uk. 